\title{
Early breakdown of the blood-retinal barrier in diabetes
}

\author{
JOSÉ CUNHA-VAZ, J. R. FARIA DE ABREU, ANTÓNIO J. CAMPOS, \\ AND GABRIELA M. FIGO \\ From the Department of Ophthalmology, University of Coimbra, Coimbra, Portugal
}

Most of our knowledge concerning the role of the blood-retinal barrier in human retinal disease has been derived through the clinical use of fluorescein angiography. A direct correlation between fluorescein 'leakage' and breakdown of the bloodretinal barrier has been established by the work of Cunha-Vaz and Maurice (1967) who demonstrated an active transport of fluorescein at the bloodretinal barrier level.

Fluorescein angiography, is not quantitative, and shows low sensitivity and reproducibility in assessing fluorescein permeability. A clinical quantitative method for the study of the blood-retinal barrier has been developed and is reported in this paper.

An alteration of the blood-retinal barrier has been proposed (Ashton, 1965; Cunha-Vaz, 1966, 1972; Norton and Gutman, 1967) as one of the earliest retinal changes in diabetes. The development of the technique of vitreous fluorophotometry prompted us to examine a series of diabetic patients, particularly those who failed to show any retinal lesions with other methods of fundus examination.

\section{Material and methods}

\section{VITREOUS FLUOROPHOTOMETRY}

To measure the fluorescein concentration in the vitreous, a model 360 Haag-Streit slit lamp was modified by adapting a new source of illumination, appropriate filters, a photometric detection system similar to that described by Waltman and Kaufman (1970) for the examination of the anterior chamber, and a device for electrical registration of the movement of the instrument.

\section{Slit lamp}

The incandescent bulb normally present in the slit lamp was replaced by a fibreoptic system connected with a $150 \mathrm{~W}$ unit and with ventilation.* A holder containing

*Weck fibreoptic light source, product of YK Hoppl Corporation

This study was supported by research grant CMC 8 from the Instituto de Alta Cultura, Portugal

Address for reprints : Professor José Cunha-Vaz, Clínica Oftalmológica, Hospitais da Universidade de Coimbra, Celas, Coimbra Portugal the removable exciting filter was mounted on the arm in front of the light source. The lamp and microscope arms were locked at an angle of $20^{\circ}$ for measurements.

\section{Microscope}

The photometric detection system $\dagger$ consisted of a modified eyepiece containing a fibreoptic probe, so designed that it could be superimposed on any area of the image of the optical cross-section, connected to a photomultiplier tube (EMI 9502), an autoranging photometer (2900), and either a recorder (500 XY) or an oscilloscope with storage (Tektronix $5 \mathrm{ro}_{3} \mathrm{~N}_{5} \mathrm{~A}_{1} 8 \mathrm{~N}_{5} \mathrm{~B}$ roN) (Fig. I). The sensor tip of the probe, which was $0.15 \mathrm{~mm}$ in diameter, focused simultaneously with the optical section, thus allowing the fluorescein concentration to be measured in all parts of the eye visible in the ocular of the slit lamp. The overall sensitivity of the instrument could be varied by adjusting the voltage across the photomultiplier tube while a standard solution of fluorescein was observed. The instrument has been shown to be stable after an initial warm-up period of about 30 minutes.

As the instrument scanned, it registered electrically by a system similar to that described by Kaiser and Maurice (1964). A linear carbon potentiometer was clamped to the slit-lamp table and a sliding contact was moved by a rod held against the base of the instrument. The output from the potentiometer was brought to the $X$ plates of the recorder. A manual switch was placed in line with the $\mathrm{Y}$ terminal of the recorder to mark the positions of the retinal and lens surfaces. All the measurements were made after application of a Worst lowvacuum contact lens to the eye under examination.

The filters used were either a Haag-Streit blue filter $(T=460 \mathrm{~nm})$ or a Balzer FITC-3 $(\mathrm{T}=460-480 \mathrm{~nm})$, with a red suppression filter as excitor and an Ilford I 10 as barrier. The instrument was operated in a darkened room.

As the recording was normally done quickly it was not difficult for the patient to maintain a steady fixation. However, to standardize the procedure, the macular region was selected for recording. The recordings were finally transferred to fluorescein concentration curves, by dividing the recording into three equal parts, which were ascribed to posterior vitreous, middle vitreous, and anterior vitreous, taking the value from six equidistant points of each third of the recording and then extrapolating each of these values.

†Supplied by Gamma Scientific Co, San Diego, California 


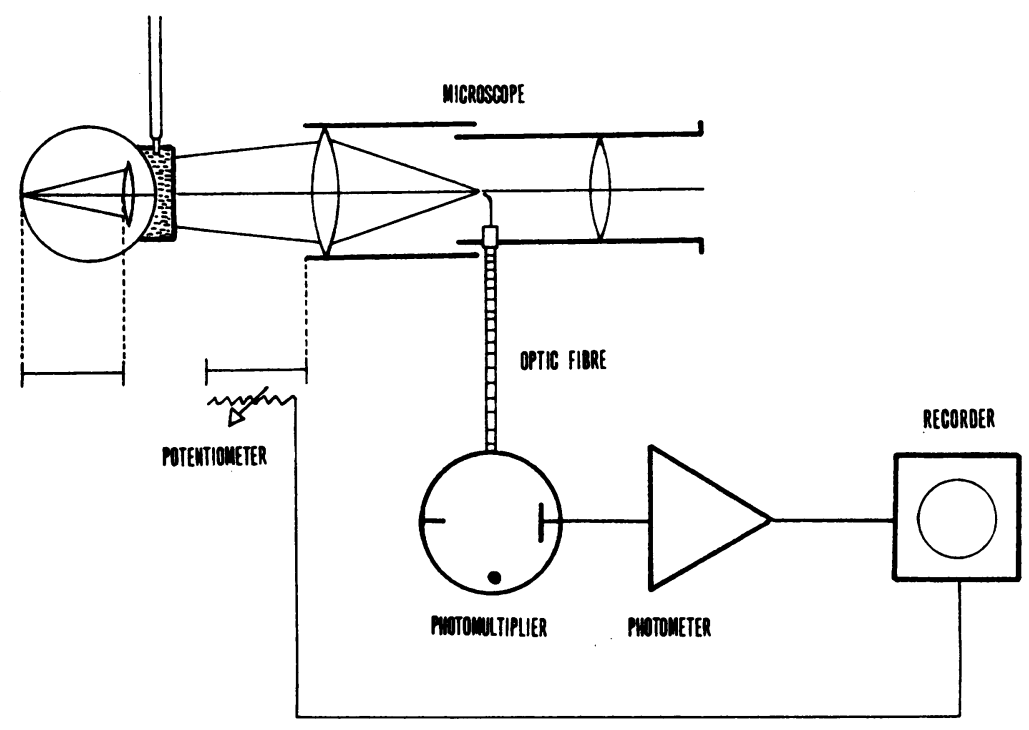

FIG. I Diagram of fluorophotometric system

\section{Validity of the method}

To test the validity of the method six adult pigmented rabbits were submitted to two experimental situations devised to check the accuracy of the method in representing the known distribution of fluorescein within the eye.

I. A small volume of fluorescein solution was injected into the vitreous and measurements were taken shortly afterwards.

2. The dye was allowed to diffuse for a few hours in the living eye after the intravitreal injection, and for a further period after the animal had been killed, and then measurements by vitreous fluorophotometry were taken.

\section{CLINICAL STUDIES}

\section{Vitreous fluorophotometry}

The visual acuity was tested for each patient and he was then examined by ophthalmoscopy, slit lamp, and fluorescein angiography before being subjected to vitreous fluorophotometry. A $10 \mathrm{ml}$ intravenous injection of ro per cent sodium fluorescein was immediately followed by fluorescence angiography, performed either with a Zeiss camera with Baird atomic filters or with the Topcon TRC-F 3 , and by vitreous fluorophotometry I hour later. For each patient at least three fluorophotometric recordings were made. Fluorescein concentration curves were plotted from the recordings.

\section{Subjects}

To test the clinical uses of the apparatus, to standardize the procedure, and to determine its value for evaluating involvement of the blood-retinal barrier in diabetes, three groups of patients were examined.

Group I (normal volunteers) included 30 eyes belonging to healthy individuals, which did not reveal any abnormality on ophthalmic examination.
Group II (diabetic patients without apparent retinal involvement) comprised 30 patients with confirmed diabetes, who are being followed-up in the diabetes clinic of the University Hospital of Coimbra. These cases were chosen because the retina was apparently normal. They had 10/10 visual acuity, and normal ophthalmoscopic, slit lamp, and fluorescein angiographical examinations. The discovery of any retinal vascular lesions, haemorrhages, or exudates automatically excluded the patient from the series.

Group III (diabetic retinopathy) included 15 diabetic patients showing different stages of diabetic retinopathy as shown by ophthalmoscopy, slit-lamp examination, and fluorescein angiography.

\section{REPRODUCIBILITY OF THE METHOD}

To test the reproducibility of the measurements obtained and to examine the possibilities of using this technique in longitudinal studies, three normal volunteers, three diabetic patients without retinopathy, and three diabetics with retinopathy were tested three times at 4-day intervals.

\section{Results}

The calibration and linearity of the response of the instrument were measured using standardized solutions in glass test-tubes. The instrument gives linear response to fluorescein concentrations between $\mathrm{I} \times 1 \mathrm{10}^{-9}$ and approximately $5 \times 10^{-5} \mathrm{~g} / \mathrm{ml}$ (Fig. 2). The sensitivity of the instrument could be increased by higher voltages being applied, although there would be increased random fluctuations in the noise output from the multiplier tube. To avoid these and obtain steady readings and recordings, a setting value of $888 \mathrm{~V}$ was chosen. 


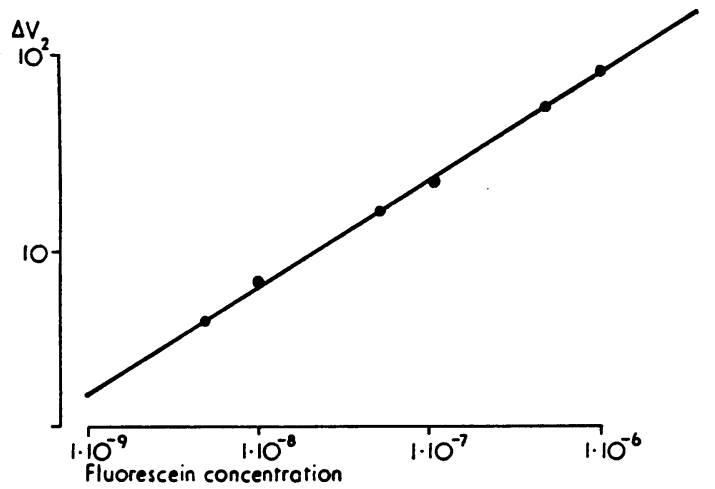

FIG. 2 Relationship between values of fluorescence measured by fluorophotometric system and fuorescein concentrations

\section{BACKGROUND}

The threshold at which fluorescein can no longer be measured in the various media of the eye is not limited by the sensitivity of the fluorophotometer but by the diffusion of light, by the tissues themselves, or by their autofluorescence. The vitreous body is itself sufficiently clear to allow fluorescein to be determined at concentrations below $10^{-9}$ $\mathrm{g} / \mathrm{ml}$. However, interference from the lens and the retina raised this threshold at the boundaries of the vitreous body, particularly in the proximity of the lens.

\section{VALIDITY OF THE METHOD}

When a small volume of fluorescein, io $\mu \mathrm{l}$, was injected into the vitreous of a rabbit eye, the fluorophotometric recording taken ro minutes after the intravitreal injection showed the gaussian distribution (Fig. 3) which was expected (Cunha-Vaz and Maurice, 1967). In the second test an attempt was

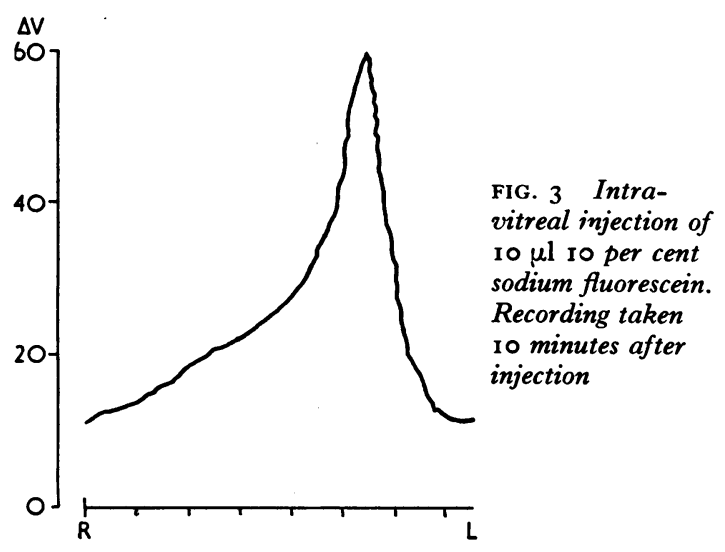

made to establish a uniform concentration throughout the vitreous. To achieve this the dye was allowed to diffuse for a few hours in the living eye and then for a further period after the animal had been killed. The fluorophotometric recording showed a flat contour throughout the vitreous body, confirming that no change in level had been introduced by the optical power of the crystalline lens of the eye.

\section{Group I-Normal volunteers}

The 30 normal eyes consistently showed a value of fluorescence in the vitreous that was well within the background limit values, and appeared to be independent of the intravenous administration of I0 $\mathrm{ml}$ of ro per cent fluorescein (Fig. 4). Exceptionally, in three patients all over 50 years of age, the recordings presented slightly higher values after the fluorescein injection, but these were never above $6 \times 10^{-9} \mathrm{~g} / \mathrm{ml}$.

\section{Group II-Diabetic patients without apparent retinal involvement}

All the patients in this group had 'normal' fundi. In spite of the 'normality' of the fluorescein an-

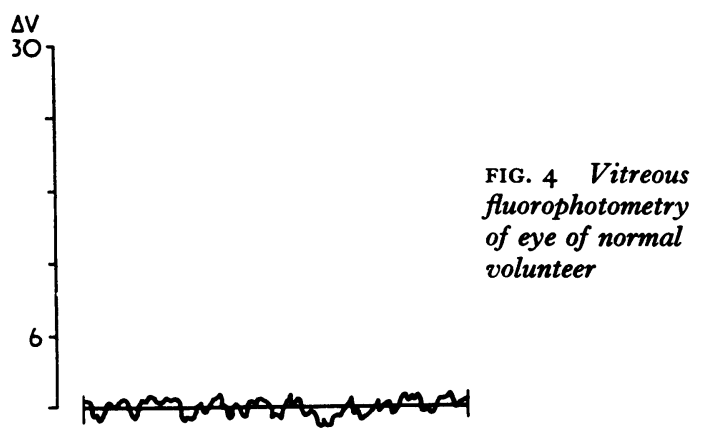

giograms where no lesions were detectable, the vitreous fluorophotometry readings were constantly above normal, showing average values of $4.27 \mathrm{~g} / \mathrm{ml}$ fluorescein in the posterior vitreous, and 3.4 and $3.1 \mathrm{~g} / \mathrm{ml}$ in the anterior and middle vitreous (Table I).

The fluorescein concentration curves obtained by vitreous fluorophotometry showed a consistently marked penetration of fluorescein into the eyes of all 30 diabetics examined. These curves followed a typical pattern (Fig. 5), although the absolute values varied from case to case. Table I shows the average values of fluorescein concentration in the vitreous of the eyes examined, and information about some diabetic parameters, namely age at 
Table I Fluorophotometric measurements in the vitreous of 30 diabetic eyes which showed no abnormalities with fluorescein angiography

\begin{tabular}{|c|c|c|c|c|c|c|}
\hline \multirow[b]{2}{*}{$\begin{array}{l}\text { Case } \\
\text { No. }\end{array}$} & \multicolumn{3}{|c|}{ Diabetic parameters } & \multicolumn{3}{|c|}{ Vitreous fluorophotometry } \\
\hline & $\begin{array}{l}\text { Age at } \\
\text { onset } \\
\text { (yrs) }\end{array}$ & $\begin{array}{l}\text { Duration } \\
\text { (yrs) }\end{array}$ & Treatment & Posterior & Middle & Anterior \\
\hline $\mathbf{I}$ & 61 & 3 & Diet & $\mathbf{2} \cdot \mathbf{I}$ & $\mathrm{I} \cdot 5$ & $1 \cdot 7$ \\
\hline 2 & 59 & $18 / 12$ & Sulphonylureas & 3 & $2 \cdot 3$ & $2 \cdot 7$ \\
\hline 3 & 45 & 4 & Sulphonylureas & $1 \cdot 9$ & I & 0.56 \\
\hline 4 & 58 & I & Sulphonylureas & $2 \cdot 3$ & $2 \cdot 1$ & $1 \cdot 8$ \\
\hline 5 & 39 & $\mathbf{I}$ & Sulphonylureas & 4.6 & $2 \cdot 6$ & $2 \cdot 0$ \\
\hline 6 & 73 & 7 & Sulphonylureas & $\mathrm{I} \cdot 9$ & 0.9 & $1 \cdot 8$ \\
\hline 7 & 56 & $6 / 12$ & Sulphonylureas & $2 \cdot 6$ & $1 \cdot 9$ & $2 \cdot 6$ \\
\hline 8 & 40 & 6 & Sulphonylureas & $3 \cdot 2$ & 3 & $2 \cdot 7$ \\
\hline 9 & 43 & 7 & Sulphonylureas & $3 \cdot 8$ & $2 \cdot 6$ & $2 \cdot 3$ \\
\hline 10 & 62 & 3 & Sulphonylureas & $3 \cdot 3$ & 0.56 & $c \cdot 56$ \\
\hline II & 39 & 3 & Insulin & $4 \cdot 6$ & $2 \cdot 7$ & $2 \cdot 6$ \\
\hline 12 & 68 & 6 & Sulphonylureas & $3 \cdot 2$ & $3 \cdot 4$ & $4 \cdot 2$ \\
\hline 13 & 39 & 3 & Sulphonylureas & 4.7 & $3 \cdot 9$ & $4 \cdot 4$ \\
\hline 14 & $5^{8}$ & $\mathbf{r}$ & Sulphonylureas & $2 \cdot 3$ & $\mathrm{I} \cdot 4$ & $2 \cdot 6$ \\
\hline I5 & 67 & $7 / 12$ & Sulphonylureas & 4.8 & $4 \cdot 6$ & $4 \cdot 6$ \\
\hline 16 & 35 & 7 & Sulphonylureas & $3 \cdot 8$ & $2 \cdot 6$ & $3 \cdot 3$ \\
\hline 17 & 23 & 3 & Insulin & $6 \cdot 2$ & $3 \cdot 2$ & $3 \cdot 5$ \\
\hline 18 & 13 & $1 / 12$ & Insulin & $7 \cdot 4$ & $4 \cdot 2$ & $4 \cdot 4$ \\
\hline 19 & 64 & 2 & Sulphonylureas & 3.9 & $2 \cdot 4$ & $3 \cdot 3$ \\
\hline 20 & 59 & 1 & Sulphonylureas & $2 \cdot 7$ & $2 \cdot 1$ & $2 \cdot 3$ \\
\hline 21 & 45 & 13 & Insulin & 6.8 & $4 \cdot 2$ & $5 \cdot 8$ \\
\hline 22 & 42 & 4 & Insulin & 15 & I $3 \cdot 1$ & $12 \cdot 8$ \\
\hline 23 & 29 & 4 & Insulin & $6 \cdot 7$ & $4 \cdot 6$ & $5 \cdot 4$ \\
\hline 24 & 56 & 2 & Diet & $2 \cdot 2$ & $1 \cdot 8$ & $1 \cdot 9$ \\
\hline 25 & 73 & 4 & Sulphonylureas & $5 \cdot 1$ & $4 \cdot 8$ & $5 \cdot 3$ \\
\hline 26 & 55 & I & Sulphonylureas & $3 \cdot 5$ & $2 \cdot 1$ & $3 \cdot 4$ \\
\hline 27 & 59 & I & Sulphonylureas & $7 \cdot 4$ & $6 \cdot 6$ & $5 \cdot 8$ \\
\hline 28 & 54 & 2 & Sulphonylureas & $2 \cdot 4$ & $2 \cdot \mathbf{I}$ & $2 \cdot 2$ \\
\hline 29 & 62 & 2 & Diet & $2 \cdot 1$ & 0.9 & $I \cdot 4$ \\
\hline \multirow[t]{2}{*}{30} & 60 & 4 & Sulphonylureas & $4 \cdot 5$ & $4 \cdot 2$ & 4 \\
\hline & & & Mean values & $4 \cdot 27$ & $3 \cdot 11$ & $3 \cdot 4$ \\
\hline
\end{tabular}

onset, duration, and treatment at the time of vitreous fluorophotometry.

\section{Group III-Diabetic retinopathy}

The eyes of the 15 diabetic patients included in this group showed clear evidence of diabetic retinopathy, from simple microaneurysms and a few haemorrhages and exudates to very advanced lesions with marked capillary closure, preferential channels, and neovessel formation. The recordings obtained from these eyes showed much higher values of fluorescein in the vitreous, usually of the order of $2 \times 10^{-7} \mathrm{~g} / \mathrm{ml}$ (Figs 6 and 7), but sometimes reaching values as high as $4 \times 10^{-6} \mathrm{~g} / \mathrm{ml}$ (Figs 8 and 9). In Table II the $I_{5}$ cases of diabetic retinopathy examined are listed correlating a few diabetic parameters, the visual acuity, and the relative incidence of their main lesions with the results of vitreous fluorophotometry.

\section{REPRODUCIBILITY OF THE METHOD}

The fluorophotometric measurements obtained in the vitreous in the three groups of patients examined showed that they were reproducible for the short interval, 4 days, used. The values registered in the diabetic patients are presented in Table III. These show that in those with severe leakage the reproducibility is within \pm 3 per cent. Those with least leakage show greater variation, but even here the method has a variability of under \pm ro per cent. In the normal volunteers the values found were constantly within the background 

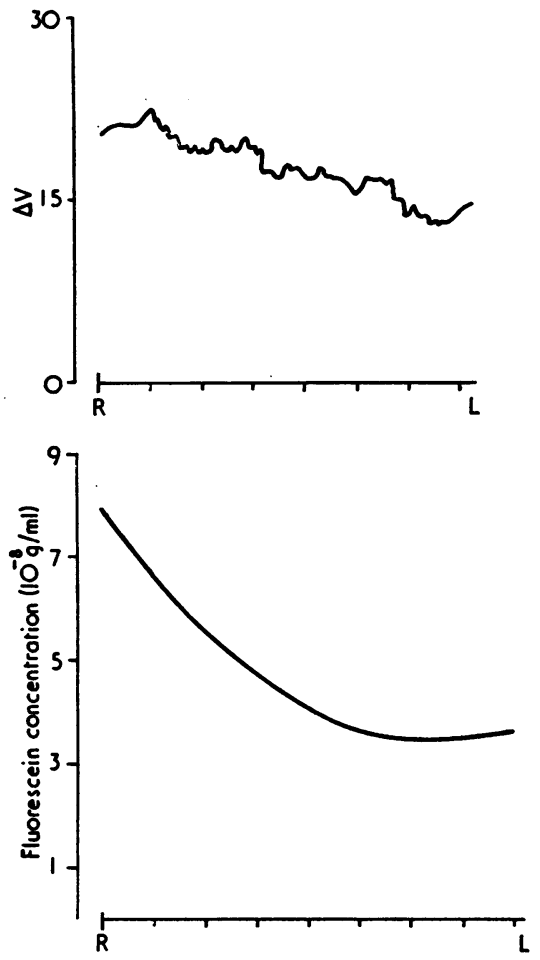

FIG. 5 Vitreous fluorophotometry of eye of diabetic patient which revealed no abnormality with fluorescein angiography. Upper, recording; Lower, plotted curve of fluorescein concentration. $R$-retina; $L$-lens

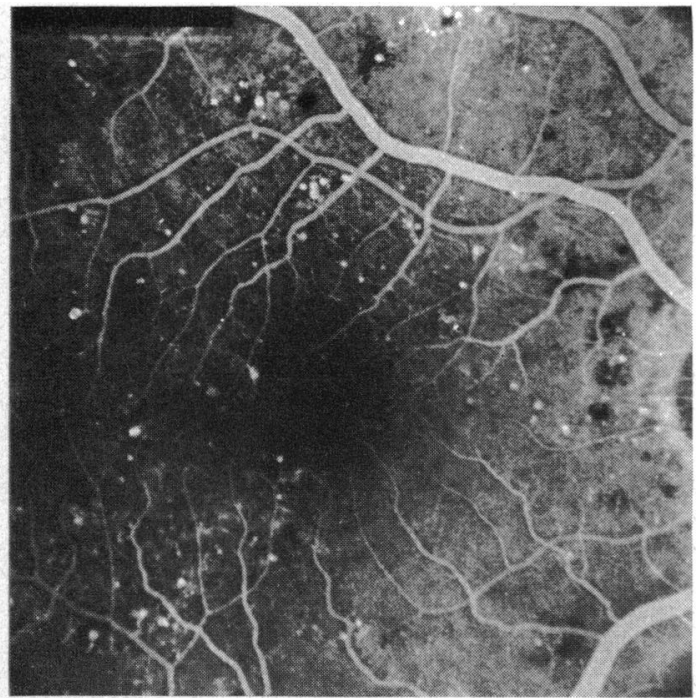

FIG. 6 Fluorescein angiography showing microaneurysms in macular area in relatively mild case of diabetic retinopathy limits and corresponded well in the different examinations.

\section{Discussion}

A new clinical method for the study of the bloodretinal barrier is presented, which appears to satisfy all the conditions previously considered to be important-it is quantitative and shows good reproducibility and high sensitivity. Furthermore this method is not time-consuming and when done without concomitant angiography can be performed using much smaller amounts of fluorescein. Such a possibility facilitates repeated studies at shorter intervals. A somewhat similar fluorophotometric system has been devised by BenSira and Riva (1973), but their technique does not enable one to study the intravitreal penetration of fluorescein.

Our studies confirm the marked impermeability of the retinal vessels in man to fluorescein in the blood, a finding previously demonstrated in experimental studies (Cunha-Vaz and Maurice, 1967). Moreover, the fluorophotometric values obtained in man agree with the experimental results, supporting the view that an active transit mechanism for organic anions must be present at the level of the blood-retinal barrier in man.

The examination of a number of diabetic patients presenting different degrees of retinal involvement showed a significant breakdown of the

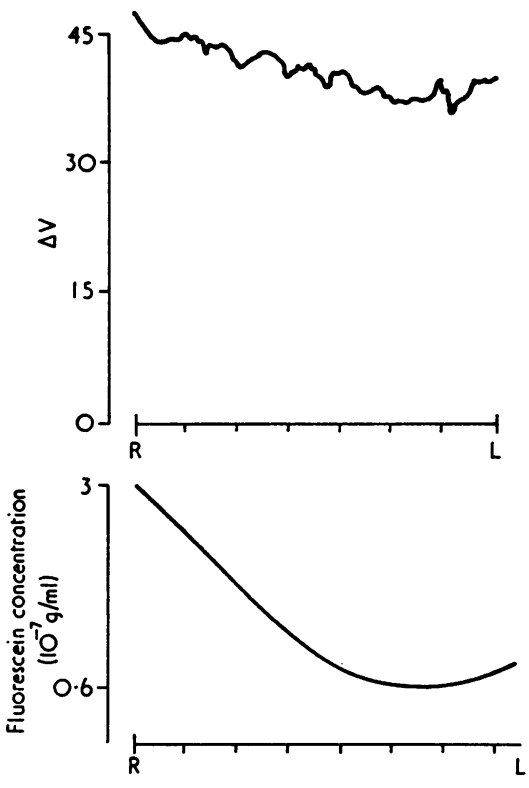

FIG. 7 Vitreous fluorophotometry of case represented in Fig. 6. Upper, recording; Lower, plotted curve of fluorescein concentration. $R$-retina; $L$-lens 
Table II Fluorophotometric measurements in the vitreous of 15 eyes with overt diabetic retinopathy

\begin{tabular}{|c|c|c|c|c|c|c|c|c|c|c|c|c|c|}
\hline \multirow{2}{*}{$\begin{array}{l}\text { Case } \\
\text { No. }\end{array}$} & \multicolumn{3}{|c|}{ Diabetic parameters } & \multirow{2}{*}{$\begin{array}{l}\text { Visual } \\
\text { acuity }\end{array}$} & \multicolumn{5}{|c|}{ Fluorescein angiography } & \multicolumn{3}{|c|}{ Vitreous fluorophotometry } & \multirow{2}{*}{$\begin{array}{l}\text { Obser- } \\
\text { vations }\end{array}$} \\
\hline & $\begin{array}{l}\text { Age } \\
\text { at } \\
\text { onset } \\
\text { (yrs) }\end{array}$ & $\begin{array}{l}\text { Dura- } \\
\text { tion } \\
\text { (yrs) }\end{array}$ & Treatment & & Exudates & Leakage & $\begin{array}{l}\text { Micro- } \\
\text { aneurysms }\end{array}$ & $\begin{array}{l}\text { Capillary } \\
\text { closure }\end{array}$ & $\begin{array}{l}\text { Prefer- } \\
\text { ential } \\
\text { channels }\end{array}$ & Posterior & or Middle & Anterior & \\
\hline 31 & 46 & 4 & Sulphonylureas & $5 / 10$ & * & + & $\begin{array}{l}\S \\
\S \\
\S \\
\S \\
\S\end{array}$ & T & $\|$ & $18 \cdot 1$ & $16 \cdot 7$ & $16 \cdot 2$ & \\
\hline 32 & 45 & 4 & Diet & 10/10 & $\begin{array}{l}* \\
* \\
*\end{array}$ & $\begin{array}{l}+ \\
+ \\
+ \\
+\end{array}$ & $\begin{array}{l}\S \\
\S \\
\$ \\
\S \\
\S\end{array}$ & T & $\|$ & 12 & $10 \cdot 2$ & $9 \cdot 3$ & \\
\hline 33 & 53 & $\mathbf{I}$ & Sulphonylureas & $4 / 10$ & $*$ & $\begin{array}{l}+ \\
+ \\
+\end{array}$ & $\S$ & T & $\|$ & 40 & 21 & 22 & \\
\hline 34 & 42 & 30 & Sulphonylureas & $5: 10$ & $*$ & $\begin{array}{l}\dagger \\
+\end{array}$ & $\S$ & I & & 22 & 19 & 20.5 & \\
\hline 35 & 36 & 15 & Sulphonylureas & $10: 10$ & $\begin{array}{l}* \\
* \\
*\end{array}$ & $\begin{array}{l}+ \\
+ \\
+ \\
+ \\
+\end{array}$ & $\begin{array}{l}\S \\
\S \\
\S \\
\$ \\
\S\end{array}$ & $\begin{array}{l}\text { T } \\
\text { T } \\
\text { Tे }\end{array}$ & $\begin{array}{l}\| \\
\| \\
\|\end{array}$ & $9 \cdot 6$ & $8 \cdot 7$ & $8 \cdot 9$ & New \\
\hline 36 & $4 I$ & 13 & Insulin & $2: 10$ & $\begin{array}{l}* \\
* \\
*\end{array}$ & $\begin{array}{l}+ \\
+ \\
+ \\
+\end{array}$ & $\S$ & T & \| & 350 & 240 & 170 & vessels \\
\hline 37 & 66 & 6 & Sulphonylureas & 410 & $*$ & + & $\$$ & T & il & 2.4 & 20.5 & 23 & \\
\hline 38 & 59 & 3 & Sulphonylureas & $8 / 10$ & $*$ & $\begin{array}{l}+ \\
+ \\
+\end{array}$ & $\begin{array}{l}\$ \\
\S \\
\$ \\
\S\end{array}$ & I & $\|$ & I9 & $11 \cdot 1$ & $7 \cdot 3$ & \\
\hline 39 & 5I & 5 & Sulphonylureas & $10 / 10$ & $*$ & + & $\begin{array}{l}\S \\
\S \\
\S\end{array}$ & ণิ & $\|$ & $20 \cdot 1$ & 16 & $\begin{array}{l}17 \\
7 \cdot 2\end{array}$ & \\
\hline 40 & 49 & 2 & Sulphonylureas & 9/10 & $*$ & + & $\begin{array}{l}\S \\
\S \\
\S \\
\S\end{array}$ & $\begin{array}{l}\text { ๆ } \\
\text { Tे } \\
\text { Tे } \\
\text { T }\end{array}$ & $\begin{array}{l}\| \\
\| \\
\|\end{array}$ & $7 \cdot 4$ & $6 \cdot 5$ & $7 \cdot 2$ & \\
\hline 41 & 40 & 20 & Sulphonylureas & I/10 & $\begin{array}{l}* \\
*\end{array}$ & $\begin{array}{l}+ \\
+\end{array}$ & $\begin{array}{l}\S \\
\$ \\
\S \\
\S\end{array}$ & $\begin{array}{l}T \\
T \\
T \\
T\end{array}$ & $\begin{array}{l}\| \\
\| \\
\|\end{array}$ & 31 & 25 & 28 & \\
\hline 42 & 54 & 15 & Sulphonylureas & $1 / 10$ & $*$ & $\dagger$ & $\begin{array}{l}\dddot{\S} \\
\S \\
\S\end{array}$ & T & $\|$ & 32 & 28 & 29 & $\begin{array}{l}\text { Lpacities } \\
\text { opas }\end{array}$ \\
\hline 43 & $6 \mathrm{I}$ & 7 & Sulphonylureas & 1/10 & * & $\begin{array}{l}+ \\
+ \\
+\end{array}$ & $\begin{array}{l}\S \\
\S \\
\S \\
\S\end{array}$ & $\begin{array}{l}T \\
\text { T } \\
\text { T }\end{array}$ & $\|$ & 28 & 22 & 24 & $\begin{array}{l}\text { Lens } \\
\text { opacities }\end{array}$ \\
\hline 44 & 54 & 8 & Sulphonylureas & $9 / 10$ & $\begin{array}{l}* \\
* \\
*\end{array}$ & $\begin{array}{l}+ \\
+ \\
+ \\
+ \\
+\end{array}$ & $\S$ & I & & $I I \cdot I$ & $9 \cdot 8$ & $9 \cdot 6$ & \\
\hline 45 & 39 & 17 & Insulin & $3 / 10$ & * & $\dagger$ & $\S$ & $\pi$ & & 120 & 85 & 90 & \\
\hline
\end{tabular}

blood-retinal barrier in every diabetic eye examined. Furthermore, it was found that the disturbance of the blood-retinal barrier, as shown by vitreous fluorophotometry, appears before any lesion is clinically visible in the fundus such as capillary closure and microaneurysms. These can be seen clearly by fluorescein angiography and are usually considered to be the first lesions to appear in the retina in cases of diabetes.

This study shows that a breakdown of the blood-retinal barrier, possibly functional, is undoubtedly one of the earliest changes known to occur in the retina in diabetes, a finding which must have great significance in the pathophysiology of diabetic retinopathy.

Experimental work has shown that a breakdown of the blood-retinal barrier can be induced by a surcharge of organic anions through a process of $\bar{\sigma}$ competitive inhibition (Cunha-Vaz and Maurice, 1967). 
Table III Vitreous fluorophotometry repeated (3 tests) at intervals of 4 days in two series each of three diabetic patients $\left(\times \mathrm{10}^{-8} \mathrm{~g} / \mathrm{ml}\right)$

\begin{tabular}{|c|c|c|c|c|c|c|c|c|c|c|}
\hline \multirow{2}{*}{$\begin{array}{l}\text { Diabetic } \\
\text { patients }\end{array}$} & \multirow{2}{*}{ Test } & \multicolumn{9}{|l|}{ Vitreous } \\
\hline & & Posterior & Middle & Anterior & Posterior & Middle & Anterior & Posterior & Middle & Anterior \\
\hline $\begin{array}{l}\text { Without } \\
\text { overt } \\
\text { retinopathy }\end{array}$ & $\begin{array}{l}\text { First } \\
\text { Second } \\
\text { Third }\end{array}$ & $\begin{array}{l}3 \cdot 0 \\
2 \cdot 8 \\
3 \cdot 2\end{array}$ & $\begin{array}{l}2 \cdot 0 \\
1 \cdot 7 \\
2 \cdot 1\end{array}$ & $\begin{array}{l}2 \cdot 7 \\
2 \cdot 4 \\
2 \cdot 7\end{array}$ & $\begin{array}{l}11 \\
11 \\
12\end{array}$ & $\begin{array}{l}7 \cdot 8 \\
8 \cdot 0 \\
7 \cdot 9\end{array}$ & $\begin{array}{l}7 \cdot 8 \\
7 \cdot 9 \\
7 \cdot 9\end{array}$ & $\begin{array}{l}9 \\
9.5 \\
10.5\end{array}$ & $\begin{array}{l}6 \cdot 8 \\
7 \cdot 0 \\
7 \cdot 1\end{array}$ & $\begin{array}{l}7 \cdot 4 \\
7 \cdot 7 \\
7 \cdot 7\end{array}$ \\
\hline $\begin{array}{l}\text { With } \\
\text { overt } \\
\text { retinopathy }\end{array}$ & $\begin{array}{l}\text { First } \\
\text { Second } \\
\text { Third }\end{array}$ & $\begin{array}{l}41 \\
41 \\
41\end{array}$ & $\begin{array}{l}33 \\
33 \\
32\end{array}$ & $\begin{array}{l}28 \\
27 \\
29\end{array}$ & $\begin{array}{l}26 \\
27 \\
27\end{array}$ & $\begin{array}{l}22 \\
22 \\
23\end{array}$ & $\begin{array}{l}20 \\
21 \\
21\end{array}$ & $\begin{array}{l}36 \\
35 \\
37\end{array}$ & $\begin{array}{l}28 \\
28 \\
30\end{array}$ & $\begin{array}{l}28 \\
30 \\
30\end{array}$ \\
\hline
\end{tabular}

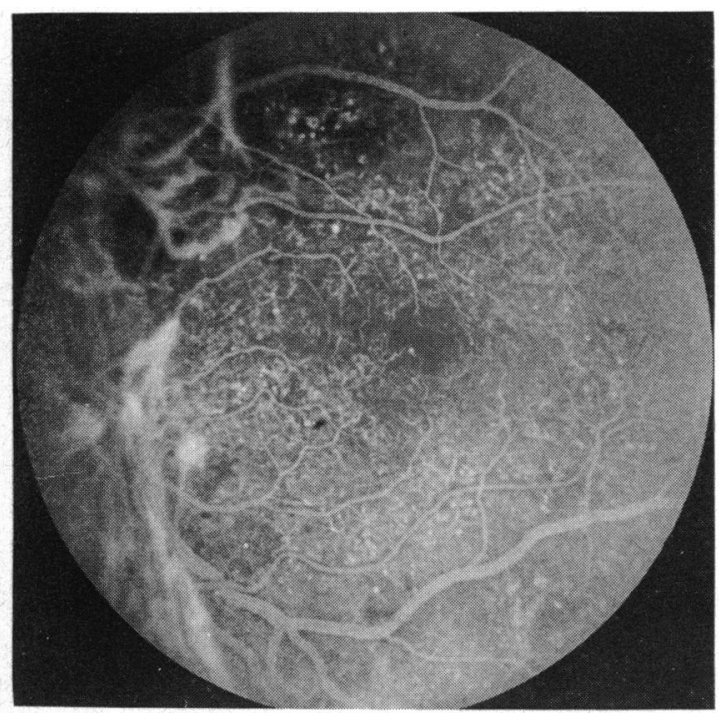

FIG. 8 Fluorescein angiography showing marked retinal involvement with various 'leaky' lesions in advanced case of diabetic retinopathy
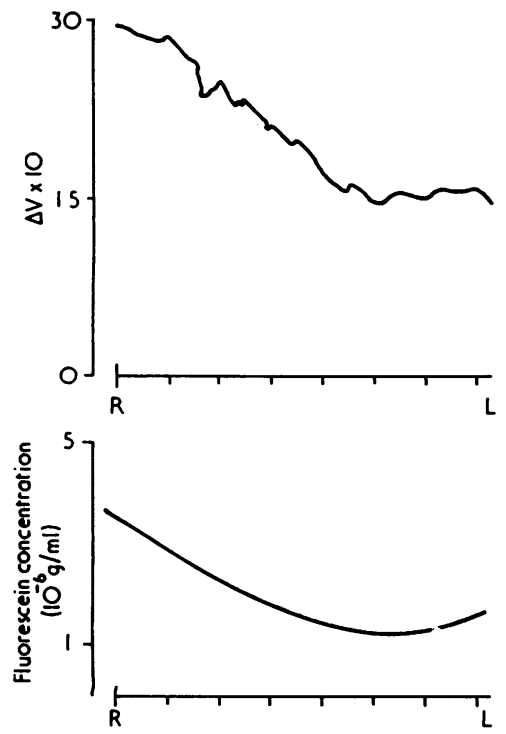

It is worth recalling that glucuronate conjugates behave as organic anions and are probably formed in the retina in diabetes through the alternative glucoronic acid pathway (Krall, I974). A possible role of the glucuronate conjugates in the development of the early breakdown of the blood-retinal barrier in diabetes must, therefore, be borne in mind.

Another point that emerged from this study and which deserves further attention is the probable role of the alteration of the blood-retinal barrier in the progress of diabetic retinopathy, as a close correlation between the severity of the vascular lesions and higher vitreous fluorophotometry readings was clearly apparent.

Similarly, a direct relationship between the degree of breakdown of the blood-retinal barrier (as shown by the concentration profiles of fluorescein in the vitreous) and the type of diabetes involved is apparent from Tables II and III. The patients who need insulin to control their diabetes appear to present higher values of fluorescein penetration through the blood-retinal barrier than those whose diabetes is controlled by oral sulphonylureas or diet alone.

Another aspect which appears to be of great interest in regard to the future use of vitreous fluorophotometry in diabetes (bearing in mind its sensitivity and reproducibility) is its use as an accurate clinical test of permeability changes during the course of the disease.

It appears that it is now possible to keep a close watch on the development and evolution of the breakdown of the blood-retinal barrier in diabetic retinopathy. This allows for the first time much needed controlled studies on the effect of drugs and/ or diabetic control in the retinopathy of diabetes.

\section{Summary}

The blood-retinal barrier plays an important part in the processes of retinal pathophysiology. A new clinical method for the study of the bloodretinal barrier by vitreous fluorophotometry appears to satisfy the necessary requirements in that 
it is quantitative and shows good reproducibility and high sensitivity.

The application of this method to a series of diabetic patients with apparently 'normal' fundi revealed the presence of a significant breakdown of the blood-retinal barrier in the early stages of retinal involvement in diabetes. The extent of the breakdown can be measured allowing for compara- tive and evolutionary evaluations. The disturbance of the blood-retinal barrier, as evidence by vitreous fluorophotometry, appears before microaneurysms or capillary closure can be demonstrated by fluorescein angiography.

Our thanks are due to Miss $\mathbf{M}$. Alice Rodrigues and $\mathbf{M r}$ José Soares for technical assistance, and to Miss M. João Coelho for secretarial help.

\section{References}

ASHTON, N. (1965) Trans. ophthal. Soc. U.K., 85, 199 BEN-SIRA, I., and RIVA, C. E. (1973) Invest. Ophthal., 12, 310 CUNHA-VAz, J. G. (1966) PhD thesis, University of London (1972) Trans. ophthal. Soc. U.K., 92, I I I and Maurice, D. M. (1967) F. Physiol. (Lond.), 191, 467

KAISER, R. J., and MAURICE, D. M. (1964) Exp. Eye Res., 3, 156

KRAll, L. P. (1974) In 'Diabetes', Proc. Eighth Congr. Int. Diabetes Federation, ed. W. J. Malaisse, J. Pirart, and J. Vallance-Owen, pp. 645-656. Excerpta Medica, Amsterdam NORTON, E. W., and GUTMaN, F. (1967) In 'Vascular Complications of Diabetes Mellitus', ed. S. J. Kimura and

W. M. Caygill, pp. 120-136. Mosby, St Louis

Waltman, s. R., and KaUfman, H. E. (1970) Invest. Ophthal., 9, 247 